\title{
PROGRAM SAKERA JEMPOL (SADARI KEKERASAN PEREMPUAN DAN ANAK DENGAN JEMPUT BOLA) KABUPATEN PASURUAN PERSPEKTIF YURIDIS
}

\author{
Hadaita Na'mah \\ Jl. Hasanuddin Cangkring Malang Beji Pasuruan. Email: \\ hadaitanamah@gmail.com.
}

\begin{abstract}
This article examines the implementation of the Sakera Jempol program (Realizing the Violence of Women and Children with Ball Pick) in Pasuruan Regency and the Effectiveness of Law No. 23 of 2004 concerning the Elimination of Domestic Violence Against the Government's Pasuruan Regency program. The data of this study are collected from observation, interviews, and documentation. Data are then analyzed using descriptive methods with inductive mindset, which describe the results of the research systematically and then seen using a juridical perspective. Based on data in the field, the Sakera Jempol Program is a program for handling victims of domestic violence, such as health services, counseling, rehabilitation, and legal assistance. The effectiveness of this program in reducing the number of violence, seen from the graph of the distribution of the number of cases of violence against women and children in the 2015-2018 period, succeeded in reducing cases from 68 cases to 21 cases of Domestic Violence (KDRT). The speed of handling victims of domestic violence is seen from the graph of the speed of handling cases of violence against women and children in the 2015-2018 period, from 5 days to 1 day. This program, if viewed from the reporting and protection stages, the handling phase, and the rehabilitation phase, is in accordance with Law No. 23 of 2004 concerning the Elimination of Domestic Violence.
\end{abstract}

Keywords: Effectiveness, Sakera Jempol program, and juridical perspective

\begin{abstract}
Abstrak: artikel ini mengkaji pelaksanaan program Sakera Jempol (Sadari Kekerasan Perempuan dan Anak dengan Jemput Bola) Kabupaten Pasuruan dan Efektivitas Undang-Undang No 23 Tahun 2004 Tentang Penghapusan Kekerasan dalam Rumah tangga Terhadap program pemerintah Kabupaten Pasuruan tersebut. Data penelitian ini dihimpun dari observasi, wawancara, dan dokumentasi. Data kemudian dianalisis menggunakan metode deskriptif dengan pola pikir induktif, yakni menggambarkan hasil penelitian secara sistematis kemudian dilihat menggunakan perspektif yuridis. Berdasarkan data di lapangan, Program Sakera Jempol adalah program penanganan korban Kekerasan dalam Rumah Tangga, seperti pelayanan kesehatan, konseling, rehabilitasi, dan pendampingan hukum. Efektivitas program ini dalam menurunkan angka kekerasan, dilihat dari grafik distribusi jumlah kasus kekerasan perempuan dan anak periode 2015-2018, berhasil menurunkan kasus dari 68 kasus menjadi 21 kasus Kekerasan Dalam Rumah Tangga (KDRT). Kecepatan waktu penanganan
\end{abstract}

AL-HUKAMA

The Indonesian Journal of Islamic Family Law

Volume 08, Nomor 02, Desember 2018; ISSN:2089-7480 
korban KDRT, dilihat dari grafik kecepatan penanganan kasus kekerasan perempuan dan anak pada periode 2015-2018, dari 5 hari menjadi 1 hari saja. Program ini, jika dilihat dari tahap pelaporan dan perlindungan, tahap penanganan, dan Tahap rehabilitasi, telah sesuai dengan Undang-Undang No 23 Tahun 2004 Tentang Penghapusan Kekerasan Dalam Rumah Tangga.

Kata Kunci: efektivitas, program Sakera Jempol, dan perspektif yuridis

\section{Pendahuluan}

Islam merupakan agama rahmatan lil alamin yang ramah pada siapapun, melindungi, menyelamatkan dan memberikan penghargaan pada semua manusia tanpa kecuali, dari beragam suku, warna kulit, perbedaan kelas sosial ekonomi hingga perbedaan lakilaki dan perempuan. Salah satu misi Rasulullah Saw dalam menegakkan Islam adalah mengangkat harkat dan martabat laki-laki maupun perempuan agar mendapatkan dan melindungi hak-hak pribadi sebagai manusia.

Karena itu Islam melakukan perubahan tatanan hukum dan perundang-undangan yang diikuti pula dengan perubahan budaya yang tercermin dalam sikap dan praktik kehidupan Rasulullah dengan melalui metode uswah hasanah.1 Disebutkan pula usaha membongkar praktik diskriminasi termasuk di antaranya diskriminasi gender sebagaimana disebutkan dalam Surat Al-Hujurat ayat 13 :

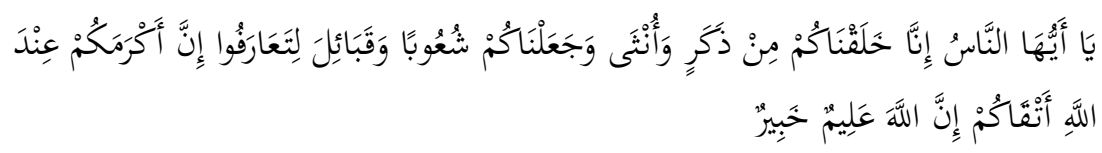

Hai manusia, sesunggubnya kami menciptakan kamu dari seorang perempuan dan menjadikan kamu berbangsa-bangsa dan bersuku-suku supaya kamu saling kenal-mengenal. Sesunggunhya orang yang paling mulia diantara kamu disis Allab SWT ialah orang yang paling taqwa diantara kamu. Sesunggubnya Allah maha mengetabui lagi Maha mengenal.2

Islam memberikan perlindungan terhadap perempuan dan anak. Kepada perempuan diberikan hak-hak sipil sebagaimana

1 Mufidah, Psikologi Keluarga Islam Berwawasan Gender (Malang: UIN-Maliki Press, $2013), 250$

2 Kementrian Agama RI, Al-Qur'an dan Terjemahnya (Jakarta: Sygma Examedia, $2009), 517$ 
diberikannya kepada laki-laki dan menghapuskan diskriminasi antara perempuan dan laki-laki dalam pemenuhan hak-hak sipilnya tersebut karena derajat perempuan sama dengan laki-laki di sisi Allah Swt, kecuali dalam hal yang bersifat fungsi utama sesuai dengan kodrat masing-masing. Tetapi perbedaan ini tidak dianggap sebagai sesuatu yang bertentangan, melainkan untuk saling melengkapi dan tolong-menolong.3

Maka dari itu perempuan dan anak-anak berhak mendapatkan perlindungan dari masyarakat dan negara agar terhindar dan terbebas dari kekerasan atau ancaman kekerasan dalam rumah tangga (KDRT), penyiksaan, atau perlakuan yang merendahkan derajat dan martabat kemanusiaan. 4

Begitu juga dengan Anak-anak berhak juga memperoleh perlindungan khusus, kesempatan, dan fasilitas yang memungkinkan mereka berkembang secara sehat dan wajar dan layak mendapatkan jaminan sosial termasuk gizi yang cukup, perumahan, pendidikan dan pelayanan kesehatan. 5

Dalam UU PKDRT Pasal 1 ayat (4), perlindungan adalah: "segala upaya yang ditujukan untuk memberikan rasa aman kepada korban yang dilakukan oleh pihak keluarga, advokat, lembaga sosial, kepolisian, kejaksaan, pengadilan, atau pihak lainnya baik sementara maupun berdasarkan penetapan pengadilan."

Tindakan kekerasan dalam rumah tangga (KDRT) memang menguras emosi dan tidak dapat terkontrol karena pikiran tindak pelaku kekerasan tersebut tertutupi oleh emosinya. Banyak dampak yang terjadi setelah terjadinya tindak kekerasan dalam rumah tangga seperti dampak pada perempuan dan pada anak. Tindak kekerasan terhadap perempuan dan anak bisa berupa fisik maupun non-fisik (psikis), dapat dilakukan secara aktif maupun pasif (tidak berbuat). Tindakan fisik langsung bisa dirasakan akibatnya oleh korban, serta dapat dilihat oleh siapa saja, sedangkan tindakan non-fisik (psikis)

3Huzaemah Tahido Yanggo, Fikih Perempuan Kontemporer (Bogor: Ghalia Indonesia, 2010 ), 139

4 Undang-Undang No. 23 Tahun 2004, Tentang Penghapusan Kekerasan Dalam Rumah Tangga

5 Shanty Dellyana, Wanita dan Anak di Mata Hukum, (Yogyakarta : Liberty, 1988), 5. 
yang bisa merasakan hanyalah korban, karena tindakan tersebut langsung menyinggung hati nurani atau perasaan seseorang.6

UU PKDRT Pasal 5 menjelaskan bahwa setiap orang dilarang melakukan kekerasan dalam rumah tangga terhadap orang dalam lingkup rumah tangganya, dengan cara :

1. Kekerasan fisik;

2. Kekerasan psikis;

3. Kekerasan seksual; atau

4. Penelantaran rumah tangga

Banyak alasan-alasan yang melatarbelakangi kekerasan dalam rumah tangga, seperti istri berakhlak buruk, istri mengabaikan hak suami, tidak menurut kepada suami, istri berselingkuh, dan masih banyak lagi. Konflik rumah tangga bisa terjadi akibat istri juga kurang memperhatikan urusan-urusan rumah seperti memasak, menyapu, mencuci, dan lain-lain. Selain alasan-alasan dari pihak istri banyak juga alasan dari pihak suami, seperti suami mudah marah, suami suka melakukan kekerasan, dan lain-lain.7

Upaya pemerintah dalam melindungi masyarakat dari adanya kekerasan fisik, psikis, seksual atau penelantaran dalam rumah tangga terhadap perempuan dan Anak adalah dengan memberlakukan Undang-Undang No 23 Tahun 2004 Tentang Penghapusan Kekerasan Dalam Rumah Tangga dan Undangundang No 22 Tahun 2002 tentang Perlindungan Anak. Agar para pelaku kekerasan jera dan tidak semena-mena dalam memperlakukan perempuan dan anak.8

Sesuai dengan UU PKDRT Pasal 11: "Pemerintah bertanggung jawab dalam upaya pencegahan kekerasan dalam rumah tangga." Undang-Undang tersebut tidak hanya memberikan gambaran tentang dilarangnya kekerasan dan sanksi-sanksi untuk para pelaku kekerasan, melainkan terdapat pencegahan, perlindungan, pemulihan, dan menyediakan pusat pelayanan bagi korban

6 Moerti Hadiati Soeroso, Kekerasan dalam Rumah Tangga dalam Perspektif YuridisViktimologis, ( Jakarta : Sinar Grafika, 2011), 60

7 Ummu Sufyan, Senarai Konflik Rumah Tangga (Bandung : Remaja Rosdakarya, 2007), 49 .

8 Ibid. 
kekerasan. Selain itu, tidak hanya korban yang dilindungi, melainkan pendamping, saksi, keluarga dan teman korban juga berhak mendapatkan perlindungan. 9

Menurut catatan tahunan Komnas Perempuan, pada tahun 2018, Angka kekerasan fisik dan seksual dalam rumah tangga di Indonesia mengalami kenaikan. Berdasarkan data Pengadilan Agama (PA), Kekerasan tertinggi yang terjadi di ranah privat/personal, yaitu sejumlah 335.062 adalah kekerasan terhadap istri yang berujung pada perceraian. Sementara dari 13.384 kasus yang masuk dari lembaga mitra pengada layanan, kekerasan yang terjadi di ranah privat/personal (pelaku adalah orang yang memiliki hubungan darah, kekerabatan, dan perkawinan) tercatat 9.609 kasus. 10

Sedangkan di Kabupaten Pasuruan, angka kekerasan dalam rumah tangga pada Tahun 2015 berjumlah 68 kasus, tahun 2016 berjumlah 68 kasus, pada tahun 2017 berjumlah 69 kasus. Pada tahun 2018, jumlah kasus kekerasan di Kabupaten Pasuruan yang tercatat di kantor Dinas KBPP (Keluarga Berencana dan Pemberdayaan Perempuan) berjumlah 21 kasus.11 Salah satu faktor permasalahan yang berasal dari masyarakat, antara lain karena kurangnya kesadaran masyarakat, khususnya masyarakat pedesaan untuk melaporkan tanda-tanda tindakan kekerasan pada perempuan dan anak sejak dini. Mereka lebih memilih menyembunyikan karena menganggap aib keluarga, khususnya kasus pelecehan seksual dan lebih memilih penyelesaian secara adat atau kekeluargaan.12

Selain itu, para korban juga lambat mendapat pelayanan, pendampingan atau bantuan hukum karena warga setempat belum memahami beberapa prosedur pelaporan. Dalam beberapa kasus,

9 Ibid.

10 Fikri Arigi, "Catatan Tahunan Komnas Perempuan" dalam Https://komnasperempuan.go.id.html diakses pada hari selasa tanggal 16 Oktober 2018.

11 Kokok Adi Prayogo, Wawancara, inovator dan subbag bagian perencanaan program, Pasuruan, 3 Januari 2019.

12 Muhajir Arifin, "Program Sakera Jempol", dalam Https://m.detik.com/news/berita-jawatimur-program-sakera-jempol.html

diakses pada hari selasa tanggal 16 Oktober 2018 jam 14:54 
proses memberikan pemahaman membutuhkan waktu tiga hari hingga satu minggu. Berdasarkan permasalahan ini, maka pemerintah Kabupaten Pasuruan memberikan solusi yang aplikatif dan komprehensif berupa program Sakera Jempol (Sadari Kekerasan Perempuan dan Anak dengan Jemput Bola), yang sudah dimulai sejak Tahun 2014.13

Banyak program-program yang tersusun dalam program Sakera Jempol, diantaranya Fanspage Plus Molin (Web dan mobil untuk perlindungan perempuan dan anak), Hotline Jempol (kartu elektronik), Four Fast (cepat terdeteksi, terlaporkan, tertangani, terehabilitasi), Advokasi Jempol (pendapingan terhadap korban kekerasan pada perempuan dan anak). Para korban akan mendapatkan pelayanan khusus melalui program-program tersebut dan masalah akan cepat teratasi. Dengan adanya program tersebut angka kekerasan dalam rumah tangga di Kabupaten Pasuruan menurun dan teratasi dengan baik.

Telah ada beberapa penelitian tentang penanganan kekerasan dalam rumah tangga, misalnya, Upaya Penanganan Korban Kekerasan dalam Rumah Tangga (KDRT) di Pusat Pelayanan Terpadu (PPT) provinsi Jawa Timur Perspektif Maqashid al-Shariah oleh Ana abdillah Tahun 2016 yang menjelaskan upaya penanganan korban KDRT di pusat Pelayanan Terpadu (PPT) Provinsi Jawa Timur, baik secara medis, medikolegal, psikososial dan hukum serta pendampingan korban melalui konseling, penyediaan rumah aman dan menjadi mediator penyelesaian sengketa bagi korban kekerasan dengan tetap menjaga kerahasiaan para korban. Upaya penanganan ini ditinjau dari perspektif Maqashid al-Shariah sudah sejalan dengan hukum Islam.

Penelitian lainnya misalnya, Penanganan Kasus Kekerasan dalam Rumah Tangga (KDRT) Badan Keluarga Berencana Pemberdayaan Masyarakat dan Pemberdayaan Perempuan (BKPMPP) di Kabupaten Sleman Yogyakarta 2012-2014 oleh Sidiq Aulia Tahun 2014 yang menjelaskan upaya penanganan korban KDRT oleh Badan Keluarga Berencana Pemberdayaan Masyarakat dan Pemberdayaan Perempuan (BKPMPP) Kabupaten Sleman. Pelayanan di Sleman terdiri dari penyediaan informasi dan layanan kesehatan yang 
terangkum dalam program sosialisasi UU PKDRT ke daerah terpencil, hingga pendampingan korban dengan memberikan fasilitas-fasilitas seperti rumah aman, konseling dan reintegrasi sosial.

Penelitian tentang Perlindungan Anak dari Tindak Kekerasan dalam Keluarga oleh Amira Paripurna Tahun 2003. Penelitian ini menjelaskan tentang perlindungan hukum terhadap anak yang mengalami tindak kekerasan dalam keluarga meliputi perlindungan dari pengabaian dan pemenuhan kebutuhan anak, perlindungan dari kekerasan seksual. Pengaturan mengenai perlindungan tersebut banyak terakomodir di dalam Undang-Undang No 23 Tahun 2004 Tentang Perlindungan Anak. Dengan adanya perlindungan hukum bagi anak dari tindak kekerasan dalam keluarga, menunjukkan bahwa kekerasan dalam keluarga bukanlah masalah pribadi keluarga yang bersangkutan, melainkan sudah menjadi masalah publik.

Sementara penelitian berjudul: Penanganan Anak Korban Kekerasan dalam Rumah Tangga di Pusat Pelayanan Terpadu "Seruni" Kota Semarang Perspektif Bimbingan Konseling Islam yang dilakukan oleh Diah Tri Puspitasari Tahun 2015, menjelaskan tentang penanganan anak korban kekerasan dalam rumah tangga di PPT "Seruni" Kota Semarang dengan penanganan tahap awal, yaitu pelaporan oleh korban atau pendamping kemudian pihak PPT melakukan wawancara awal untuk mengetahui bagaimana bentuk kekerasan yang terjadi. Korban kemudian akan mendapatkan bantuan hukum dan bantuan medis dan akan dilanjutkan dengan pemberian terapi intensif.

Dari beberapa penelitian yang pernah dilakukan, belum ada kajian tentang efektivitas Undang-Undang No 23 tahun 2004 Tentang Penghapusan Kekerasan Dalam Rumah Tangga terhadap program Sakera Jempol (Sadari Kekerasan Perempuan Dan Anak Dengan Jemput Bola) pemerintah Kabupaten Pasuruan. Program pemerintah Kabupaten Pasuruan tersebut menarik untuk dikaji dengan melihat bagaimana kesesuaiannya dengan Undang-Undang No 23 tahun 2004 Tentang Penghapusan Kekerasan Dalam Rumah Tangga.

\section{Pengertian Kekerasan Dalam Rumah Tangga (KDRT)}


Kekerasan merupakan suatu tindakan yang dilakukan oleh seseorang atau sejumlah orang yang berposisi kuat (merasa kuat) kepada seseorang atau sejumlah orang yang berposisi lemah (dipandang lemah/dilemahkan), yang dengan sarana kekuatannya, baik secara fisik maupun non-fisik dengan sengaja dilakukan untuk menimbulkan penderitaan kepada obyek kekerasan.14

Menurut UU No 23 Tahun 2004 Tentang Penghapusan Kekerasan Dalam Rumah Tangga (PKDRT) pasal 1 ayat (1):

kekerasan dalam rumah tangga adalah setiap perbuatan terhadap seseorang terutama perempuan, yang berakibat timbulnya kesengsaraan atau penderitaan secara fisik, seksual, psikologis, dan/atau penelantaran rumah tangga termasuk ancaman untuk melakukan perbuatan, pemaksaan, atau perampasan kemerdekaan secara melawan hukum dalam lingkup rumah tangga.

Secara yuridis, melakukan kekerasan adalah membuat orang menjadi pingsan atau tidak berdaya lagi (lemah). Melakukan kekerasan itu sendiri diartikan sebagai mempergunakan tenaga atas kekuatan jasmani tidak kecil secara tidak sah, misalnya memukul dengan tangan, atau dengan senjata, menendang dan sebagainya. Dengan demikian kekerasan merupakan suatu tingkah laku agresif yang dilakukan seseorang terhadap orang lain secara sengaja untuk menyebabkan korban mengalami penderitaan lahir dan batin.15

Lingkungan keluarga juga memberikan pengalaman tentang kekerasan kepada anak. Menurut La Jamaa yang mengutip pendapat dari K.durkin dalam bukunya Development Social Psychologi mengatakan, bahwa salah satu tempat terpenting sesorang belajar tentang agresi adalah keluarga, terutama dalam cara membesarkan anak. Anak-anak yang terbiasa menyaksikan kekerasan dalam keluarganya ternyata di kemudian hari akan memandang kekerasan bukan saja sebagai alternatif untuk menyelesaikan problemanya. Melainkan juga beranggapan, bahwa perilaku kekerasan itu bersifat normatif yang layak untuk dilakukan. Ini berarti, bahwa kekerasan

$14 \mathrm{Hj}$. Mufidah, Psikologi Keluarga Islam Berwawasan Gender, (Malang : UIN-MALIKI Press, 2013), 241.

15 Ibid, 50 
yang terjadi dalam lingkungan keluarga akan melahirkan kekerasan baru. 16

Sebagai suatu perilaku, kekerasan terhadap perempuan adalah suatu bentuk yang ditolak oleh siapa saja karena mengandung unsur kekerasan di dalamnya, yaitu suatu bentuk tindakan yang dilakukan satu pihak, baik pelakunya perorangan maupun lebih dari sesorang, yang dapat mengakibatkan penderitaan pada korban. Setiap tindakan kekerasan, secara reflektif tentu saja akan ditolak oleh setiap individu mengingat ada unsur pemaksaan, baik secara persuasif maupun fisik di dalamnya.17

Terminologi kekerasan terhadap perempuan mempunyai ciri bahwa tindakan tersebut:18

1. Dapat berupa fisik maupun non-fisik (psikis)

2. Dapat dilakukan secara aktif maupun dengan cara pasif (tidak berbuat).

3. Dikehendaki/diminati oleh pelaku

4. Ada akibat/kemungkinan akibat yang merugikan pada korban (fisik atau psikis), yang tidak dikehendaki oleh korban.

Menurut Farha Ciciek dalam bukunya yang berjudul Ikbtiar Mengatasi Kekerasan dalam Rumah Tangga, penganiayaan terhadap istri sebenarnya tidak terbatas pada deraan yang bersifat badani, seperti menampar, menggigit, memukul, menendang, melempar, membenturkan ke tembok sampai membunuh. Ada bentuk-bentuk penganiayaan lainnya yang bersifat kejiwaan atau emosi. Penganiayaan ini bisa dalam bentuk penanaman rasa takut melalui intimidasi, ancaman, hinaan, makian, mengecilkan arti istri, sampai membatasi ruang geraknya.19

16 La Jamaa dan Hj. Hadidjah, Hukum Islam dan Undang-undang Anti Kekerasan Dalam Rumah Tangga ( Surabaya: PT Bina Ilmu, 2013 ), 54,

17 Zohra Andi Baso Dan Dwia Aries Tina, Kekerasan Terbadap Perempuan Menghadang Langkah Perempuan (Yogyakarta: Pusat Studi Kependudukan Dan Kebijakan Universitas Gadjah Mada, 2002), 11

18 Moerti Hadiati Soeroso, Kekerasan Dalam Ruamah Tangga Dalam Perspektif Yuridis Viktimologis (Jakarta: Sinar Grafika, 2011), 59

19 Farha Ciciek, Ikbtiar Mengatasi Kekerasan dalam Rumah Tangga (Jakarta: The Asia Foundation, 1999), 24. 


\section{Bentuk dan Dampak Kekerasan Dalam Rumah Tangga}

Dari pemetaan yang dilakukan oleh Komnas perempuan diketahui, bahwa kekerasan perempuan Indonesia sangat masif penyebarannya dan mengambil bentuk yang beragam. Kekerasan tersebut terjadi baik di dalam keluarga, di tengah masyarakat maupun dalam kondisi khusus seperti konflik dan wilayah pengungsian, serta sebagai akibat langsung dan tidak langsung dari kebijakan negara. Korban kekerasan terhadap perempuan tidak hanya mengalami penderitaan fisik, psikologis atau seksual, tetapi juga terampas kemerdekaan dan teraniaya kemanusiaan. Bentuk kekerasan tersebut dapat diidentifikasi bukan hanya kekerasaan fisik, tetapi bisa berbentuk sangat halus dan tidak kasat mata seperti kecaman, kata-kata yang meremehkan dan sebagainya.20

Secara spesifik bentuk-bentuk kekerasan terhadap perempuan tertuang dalam Deklarasi Penghapusan Kekerasan Terhadap Perempuan (Declaration on the Elimination Against Women) yang diadopsi majelis PBB Tahun 1993. Pada pasal 2 dinyatakan sebagai berikut:21

a. Tindak kekerasan secara fisik, seksual, dan psikologis yang terjadi dalam keluarga, termasuk pemukulan, penyalahgunaan seksual atas anak-anak perempuan dalam rumah tangga, kekerasan yang berhubungan dengan mas kawin (mahar), perkosaan dalam perkawinan, perusakan alat kelamin perempuan, dan praktik-praktik kekejaman tradisional lain terhadap perempuan di luar hubungan suami istri, serta kekerasan yang berhubungan dengan eksploitasi.

b. Kekerasan secara fisik, seksual dan psikologis yang terjadi dalam masyarakat luas termasuk perkosaan, penyalahgunaan seksual, pelecehan dan ancaman seksual di tempat kerja, dalam lembaga-lembaga pendidikan, dan sebagainya.

c. Kekerasan secara fisik, seksual, dan psikologis yang dilakukan atau dibenarkan oleh negara.

Adapun bentuk tindak kekerasan dalam rumah tangga menurut Undang-undang Nomor 23 Tahun 2004 Tentang Penghapusan

20La Jamaa dan Hj. Hadidjah, Hukum Islam dan Undang-undang..., 64.

21 Fathul Djannah Dan Rustam, Kekerasan Terbadap Istri (Yogyakarta: LkiS Yogyakarta, 2002), 12. 
Kekerasan Dalam Rumah Tangga yang tercantum dalam Bab III tentang larangan kekerasan dalam rumah tangga pasal 5, pasal 6 , pasal 7, pasal 8, dan pasal 9, yaitu :

\section{Pasal 5}

Setiap orang dilarang melakukan kekerasan dalam rumah tangga terhadap orang dalam lingkup rumah tangganya, dengan cara :

a. Kekerasan fisik;

b. Kekerasan psikis;

c. Kekerasan seksual; atau

d. Penelantaran rumah tangga

Pasal 6

Kekerasan fisik sebagaimana dimaksud dalam pasal 5 huruf a adalah perbuatan yang mengakibatkan rasa sakit, jatuh sakit, atau luka berat.

Pasal 7

Kekerasan psikis sebagaimana dimaksud dalam Pasal 5 huruf b adalah perbuatan yang mengakibatkan ketakutan, hilangnya rasa percaya diri, hilangnya kemampuan untuk bertindak, rasa tidak berdaya dan atau penderitaan psikis berat pada seseorang. Pasal 8

Kekerasan seksual sebagaimana dimaksud dalam Pasal 5 huruf c meliputi :

a. pemaksaan hubungan seksual yang di lakukan terhadap orang yang menetap dalam lingkup rumah tangga tersebut.

b. pemaksaan hubungan seksual terhadap salah seorang dalam lingkup rumah tangganya dengan orang lain untuk tujuan komersial atau tujuan tertentu.

Pasal 9

a. Setiap orang dilarang menelantarkan orang dalam lingkup rumah tangganya, padahal menurut hukum yang berlaku baginya atau karena persetujuan atau perjanjian ia wajib memberikan kehidupan, perawatan, atau pemeliharaan kepada orang tersebut

b. Penelantaran sebagaimana dimaksud pada ayat (1) juga berlaku bagi setiap orang yang mengakibatkan ketergantungan ekonomi dengan cara membatasi dan/atau melarang untuk bekerja yang layak di dalam atau di luar 
rumah sehingga korban berada di bawah kendali orang tersebut.

Adapun dampak kekerasan dalam rumah tangga menurut Mufidah, Ch., M.Ag sebagai berikut:22

a. Dampak fisik, kekerasan fisik berdampak pada korban dalam bentuk yang bertingkat-tingkat mulai dari luka-luka, memar, lecet, gigi rompal, patah tulang, kehamilan, aborsi (keguguran), penyakit menular, atau HIV/AIDS, hingga kematian, dan mutilasi.

b. Dampak psikis, banyak yang bisa terjadi dalam pengaruhan psikis pada korban seperti gejala menangis, sering melamun, sulit kosentrasi, gangguan makan, gangguan tidur, mudah lelah, perasaan ingin bunuh diri, melampiaskan dendam pada orang lain, sering menyendiri, depresi atau menjadi gila.

c. Dampak seksual, dalam bentuk kerusakan organ reproduksi, tidak hamil, pendarahan, kemungkinan keguguran dua kali lebih tinggi bagi yang hamil, penyakit menular seksual, ASI terhenti akibat tekanan jiwa, trauma hubungan seksual, dan menopouse dini.

d. Dampak ekonomis bisa berbentuk kehilangan penghasilan dan sumber penghasilan, kehilangan tempat tinggal, harus menanggng biaya perawatan medik untuk luka fisik akibat kekerasan, harus menanggung nafkah keluarga dalam kasus penelantaran.

Pengalaman hidup dengan kekerasan, membuat korban mencoba bertahan hidup dengan cara mengurangi kekerasan yang terjadi. Hal tersebut biasanya dilakukan korban, misalnya dengan belajar tentang apa yang diinginkan pelaku dan membenarkan pandangan pelaku agar ia bisa selamat.23

\section{Hak-hak Korban Kekerasan Dalam Rumah Tangga}

Menurut UU No 23 Tahun 2004 Tentang Penghapusan Kekerasan Dalam Rumah Tangga Bab IV Tentang Hak-Hak Korban yaitu :

$22 \mathrm{Hj}$ Mufidah, Psikologi Keluarga Islam..., 248.

23 Soka Handinah, Perempuan dan Kekerasan (Jakarta: Lutfansah Mediatama, 2005), 12. 
Pasal 10

korban berhak mendapatkan :

a. Perlindungan dari pihak keluarga, kepolisian, kejaksaan, pengadilan, advokat, lembaga sosial, atau pihak lainnya baik sementara maupun berdasarkan penetapan pengadilan;

b. Pelayanan kesehatan sesuai dengan kebutuhan medis;

c. Penanganan secara khusus berkaitan dengan kerahasiaan korban;

d. Pendampingan oleh pekerja sosial dan bantuan hukum pada setiap tindak proses pemeriksaan sesuai dengan ketentuan peraturan perundang-undangan; dan

e. Pelayanan bimbingan rohani.

Adapun menurut peraturan daerah Kabupaten Pasuruan Nomor 4 Tahun 2018 Tentang Pemberdayaan Perempuan dan Perlindungan Anak Bab III Pasal 11, 12, dan 13 yaitu :

Pasal 11

Setiap perempuan dan anak mempunyai hak dasar sebagai manusia yang wajib dilindungi, dimajukan, ditegakkan dan dipenuhi sesuai ketentuan peraturan perundang-undangan.

Pasal 12

Setiap perempuan berhak untuk :

a. Hidup mempertahankan hidup dan meningkatkan taraf kehidupannya;

b. Hidup tentram, aman, damai, bahagia, sejahtera lahir dan batin;

c. Menikmati lingkungan hidup yang baik dan sehat;

d. Hidup berkeluarga dalam ikatan perkawinan yang sah berdasarkan ketentuan peraturan Perundang-undangan;

e. Memperoleh pekerjaan sesuai kemampuan, syarat-syarat serta upah yang layak dan adil;

f. Khusus bagi perempuan penyandang disabilitas, berhak untuk mendapatkan kemudahan dan perlakuan khusus dalam pelayanan publik;

g. Berperan aktif di bidang politik dan pemerintahan sesuai dengan potensi dan kemampuan yang dimilkinya;

h. Mendapatkan informasi dan pelayanan hukum; 
i. Memperoleh pelayanan untuk meningkatkan pendapatannya;

j. Dan memperoleh hak-hak lain sesuai dengan martabat kemanusiaannya dan berdasarkan ketentuan peraturan Perundang-undangan.

Jika korban sudah mendapatkan hak-hak nya sebagai korban kekerasan dalam rumah tangga sebagaimana disebutkan dalam UU PKDRT Pasal 10, 11, dan 12. Maka korban akan mendapatkan perawatan atau pelayanan dalam hal pemulihan jika terjadi kekerasan fisik terhadap tubuh korban.

Adapun aturan yang menjelaskan bahwasannya korban mendapatkan pemulihan yaitu pada UU No 23 Tahun 2004 Pasal 39, 40, 41, 42, dan 43 yaitu :

\section{Pasal 39}

Untuk kepentingan pemulihan, korban dapat memperoleh pelayanan dari :
a. Tenaga kesehatan;
b. Pekerja sosial;
c. Relawan pendamping; dan/atau
d. Pembimbing rohani.
Pasal 40

(1) tenaga kesehatan wajib memeriksa korban sesuai dengan standart profesinya.

(2) dalam hal korban memerlukan perawatan, tenaga kesehatan wajib memulihkan dan merehabilitasi kesehatan korban.

\section{Pasal 41}

Pekerja sosial, relawan, pendamping, dan/atau pembimbing rohani wajib memberikan pelayanan kepada korban dalam bentuk pemberian konseling untuk menguatkan dan/atau memberikan rasa aman bagi korban.

\section{Pasal 42}

Dalam rangka pemulihan terhadap korban, tenaga kesehatan, pekerja sosial, relawan pendamping dan/atau pembimbing rohani dapat melakukan kerja sama.

\section{Pasal 43}

Ketentuan lebih lanjut mengenai penyelenggaraan upaya pemulihan dan kerja sama diatur dengan Peraturan Pemerintah. 
Dalam hal memberikan pelayanan kesehatan, petugas kesehatan tidak hanya memberikan pelayanan medis melainkan juga membuat laporan tertulis atau hasil visum yang memiliki kekuatan hukum pemeriksaan korban KDRT untuk dijadikan sebagai alat bukti. Sesuai dengan UU No 23 Tahun 2004 Pasal 21 yaitu :

1) Dalam memberikan pelayanan kesehatan kepada korban, tenaga kesehatan harus :

a. Memeriksa kesehatan korban sesuai dengan standart profesinya

b. Membuat laporan tertulis hasil pemeriksaan terhadap korban dan visum et repertum atas permintaan penyidik kepolisian atau surat keterangan medis yang memiliki kekuatan hukum yang sama sebagai alat bukti.

2) Pelayanan kesehatan sebagaimana dimaksud pada ayat (1) dilakukan di sarana kesehatan milik pemerintah, pemerintah daerah, atau masyarakat.

Pekerja sosial juga harus memberikan pelayanan terhadap korban KDRT. Pekerja sosial biasanya melakukan konseling terhadap korban KDRT dan memberikan perlindungan yang dilakukan di rumah aman milik pemerintah, pemerintah daerah, atau masyarakat. Sesuai dengan UU No 23 Tahun 2004 Pasal 22 yaitu:

1) Dalam memberikan pelayanan, pekerja sosial harus :

a. Melakukan konseling untuk menguatkan dan memberikan rasa aman bagi korban;

b. Memberikan informasi mengenai hak-hak korban untuk mendapatkan perlindungan dari kepolisian dan penetapan perintah perlindungan dari pengadilan;

c. Mengantarkan korban ke rumah aman tau tempat tinggal alternatif, dan

d. Melakukan koordinasi yang terpadu dalam memberikan layanan kepada korban dengan pihak kepolisian, dinas sosial, lembaga sosial yang dibutuhkan korban.

2) Pelayanan pekerja sosial sebagaimana dimaksud pada ayat (1) dilakukan di rumah aman milik pemerintah, pemerintah daerah, atau masyarakat. 
Menurut Moerti Hadiati Soeroso dalam bukunya yang berjudul Kekerasan dalam Rumah Tangga dalam Perspektif Yuridis-Viktimologis. Hak-hak korban kekerasan dalam rumah tangga sebagai berikut :24

a. Korban berhak mendapatkan kompenasi atas penderitaan, sesuai dengan kemampuan pelaku.

b. Korban berhak menolak kompensasi karena tidak memerlukannya.

c. Korban berhak mendapatkan kompensasinya untuk ahli warisnya, bila korban meninggal dunia karena tindakan tersebut.

d. Korban berhak mendapatkan pembinaan dan rehabilitasi.

e. Korban berhak mendapatkan kembali hak miliknya.

f. Korban berhak menolak menjadi saksi, bila hal ini akan membahayakan dirinya.

g. Korban berhak mendapatkan perlindungan dari ancaman pihak pelaku, bila melapor ke dan menjadi saksi.

h. Korban berhak mendapat bantuan penasihat hukum.

i. Korban berhak mempergunakan upaya hukum.

Dari pemaparan UU No 23 Tahun 2004 dan pendapat dari Moerti Hadiati Soeroso di atas dapat dipahami, bahwasan korban berhak mendapatkan haknya, berhak atas perlindungan. Korban juga diperkenankan untuk mendapatkan pelayanan dan penanganan secara khusus. Jadi di sini pemerintah sangat memperhatikan para korban kekerasan dalam rumah tangga khususnya pada perempuan dan Anak. Pemerintah harus bertanggung jawab dalam upaya pencegahan kekerasan dalam rumah tangga. Sesuai dengan UU No 23 Tahun 2004 tentang PKDRT Pasal 11 "pemerintah bertanggung jawab dalam upaya pencegahan kekerasan dalam rumah tangga".

\section{Kewajiban Pemerintah dan Masyarakat Terhadap Kekerasan Dalam Rumah Tangga}

Adapun menurut Undang-undang No 23 Tahun 2004 Bab V Tentang Kewajiban Pemerintah dan Masyarakat yaitu:25

Pasal 11

24 Moerti Hadiati Soeroso, Kekerasan dalam Rumah,... 115

25 Undang-Undang No 23 Tahun 2004 
Pemerintah bertanggung jawab dalam upaya pencegahan kekerasan dalam rumah tangga.

Pasal 12

1) Untuk melaksanakan ketentuan sebagaimana dimaksud dalam pasal 11, pemerintah:

a. Merumuskan kebijakan tentang penghapusan kekerasan dalam rumah tangga;

b. Menyelenggarakan komunikasi, informasi, dan edukasi tentang kekerasan dalam rumah tangga; dan

c. Menyelenggarakan sosialisasi dan advokasi tentanf kekerasan dalam rumah tangga; dan

d. Menyelenggarakan pendidikan dan pelatihan sensitif gender dan isu kekerasan dalam rumah tangga serta menetapkan standar dan akreditasi pelayanan yang sensitif gender.

2) Ketentuan sebagaimana dimaksud dalam ayat 1 dilaksanakan oleh menteri

3) Menteri dapat melakukan koordinasi dengan instansi terkait dalam melaksanakan ketentuan sebagaimana dimaksud pada ayat 2.

Pasal 13

Untuk penyelenggaran pelayanan terhadap korban, pemerintah dan pemerintah daerah sesuai dengan fungsi dan tugas masingmasing dapar melakukan upaya :

a. Penyediaan ruang pelayanan khusus di kantor kepolisian;

b. Penyediaan aparat, tenaga kesehatan, pekerja sosial, dan pembimbing rohani;

c. Pembuatan dan pengembangan sistem dan mekanisme kerja sama program pelayanan yang melibatkan pihak yang mudah diakses oleh korban; dan

d. Memberikan perlindungan bagi pendamping, saksi, keluarga, dan teman korban.

Pasal 14

Untuk menyelenggarakan upaya sebagaimana dimaksud dalam pasal 13, pemerintah dan pemerintah daerah sesuai dengan fungsi dan tugas masing-masing, dapat melakukan kerja sama dengan masyarakat atau lembaga sosial lainya. 


\section{Pasal 15}

Setiap orang yang mendengar, melihat, atau mengetahui terjadinya kekerasan dalam rumah tangga wajib melakukan upaya-upaya sesuai dengan batas kemampuannya untuk:

a. Mencegah berlangsungnya tindak pidana;

b. Memberikan perlindungan kepada korban;

c. Memberikan pertolongan darurat; dan

d. Membantu proses pengajuan permohonan penetapan perlindungan.

Adapun dalam peraturan daerah Kabupaten Pasuruan Nomor 4 Tahun 2018 tentang Pemberdayaan Perempuan dan Perlindungan Anak yaitu :

Pasal 14

Setiap orang wajib :

a. Memenuhi hak-hak perempuan sebagaimana dimaksud dalam Pasal 12, dan

b. Memenuhi hak-hak anak sebagaimana dimaksud dalam Pasal 13.

\section{Deskripsi Program Sakera Jempol (Sadari Kekerasan Perempuan dan Anak dengan Jemput Bola)}

Program Sakera Jempol (Sadari Kekerasan Perempuan dan Anak dengan Jemput Bola) adalah pelayanan publik dalam hal pencegahan kasus kekerasan perempuan dan anak yang diciptakan untuk mengurangi angka kekerasan pada perempuan dan anak, khususnya pada masyarakat pedesaan dengan akses pelaporan yang minim, masyarakat dengan kondisi sosial ekonomi yang rendah, keluarga Broken Home, dan keluarga dengan konflik orang tua dan perceraian.

Program yang lahir pada tahun 2016 ini dilatarbelakangi adanya masalah yang terjadi pada tahun 2015, yaitu meningkatnya angka kekerasan dalam rumah tangga. Program ini dirancang oleh staff Dinas Keluarga Berencana Dan Pemberdayaan Perempuan (KBPP). Rekapitulasi data tersebut bersumber dari data laporan tahunan Kantor Dinas KBPP Kabupaten Pasuruan. Tingginya angka kekerasan yang terjadi pada perempuan dan anak pada tahun 2015 tersebut membuat para staff Dinas KBPP membuat inisiatif program untuk menanggulangi angka kekerasan tersebut. 
Program ini ditujukan untuk meningkatkan pelayanan publik dan mengakhiri kekerasan terhadap perempuan dan anak.26 Berbagai kasus kekerasan yang ditangani diantaranya kekerasan fisik, seksual, dan psikologis. Kasus kekerasan yang terbanyak adalah kekerasan seksual.27

Program ini didukung oleh peraturan Daerah Kabupaten Pasuruan Tentang Pemberdayaan Perempuan dan Perlindungan Anak, Surat Keputusan Bupati Pasuruan Nomor: 260/532/HK/424.014/ 2017 tentang Pembentukan Pejabat Pusat Layanan Terpadu Perlindungan Perempuan dan Anak Pasuruan, dan Keputusan Bupati tentang Pembentukan Kelompok Konselor/Penasehat untuk Korban Tindak Kekerasan terhadap Perempuan dan Anak di tingkat Kecamatan.

Program ini mempunyai tiga tujuan utama. Pertama menurunkan angka kekerasan terhadap perempuan dan anak. Kedua, meningkatkan kecepatan penanganan (respond time) korban kekerasan pada perempuan dan anak. Ketiga, mendampingi korban kekerasan pada perempuan dan anak secara paripurna. Selama ini, korban kekerasan kurang mendapat pendampingan yang memadai secara hukum, psikologi, dan sosial. Inisiatif ini menawarkan jalan lain, yakni pendampingan berkelanjutan sampai korban beradaptasi di lingkungannya dan bagi korban perempuan, diberikan ketrampilan tambahan sehingga mampu mandiri secara ekonomi.28

Program ini bersifat inovatif karena memanfaatkan informan kunci, yaitu para kader yang berjumlah 365 yang ditempatkan di 365 desa, 55 penyuluh, dan 24 koordinator penyuluh yang ditempatkan di 24 kecamatan, perangkat desa, tokoh masyarakat, serta keluarga sehingga korban tidak sendiri, tetapi didampingi oleh para informan kunci saat melaporkan kasusnya.

26 Kokok Adi Prayogo, Wawancara, inovator dan subbag bagian perencanaan program, Pasuruan, 3 januari 2019.

27 Ibid.

28 Kokok Adi Prayogo, Wawancara, inovator dan subbag bagian perencanaan program, Pasuruan, 3 januari 2019. 


\section{Penanganan Korban KDRT Melalui Program Sakera Jempol (Sadari Kekerasan Perempuan dan Anak dengan Jemput Bola)}

\section{Prosedur Penanganan Korban KDRT}

Dalam menangani korban kekerasan dalam rumah tangga (KDRT), biasanya korban yang datang ke kantor Dinas Keluarga Berencana dan Pemberdayaan dan Perempuan (KBPP) Kabupaten Pasuruan diantar oleh kader di daerah korban tersebut berasal, keluarga, atau datang sendiri. Dengan didampingi kader, korban korban mengisi kartu aduan yang telah diberikan kader. Korban kekerasan akan mendapatkan upaya penanganan secara cepat dalam sehari. Apabila korban mengalami luka fisik, maka akan divisum di Rumah sakit yang telah bekerja sama dengan Kantor KBPP. Namun apabila keadaan korban baik dan tidak ada luka fisik, maka korban akan dibawa ke kantor KBPP Kabupaten Pasuruan untuk mendapatkan pendampingan awal oleh perawat atau pegawai kantor dinas KBPP guna mengetahui peristiwa yang terjadi secara umum agar dapat diketahui keadaan psikologis korban. Jika terjadi gangguan psikologis pada korban, maka akan didampingi secara menyeluruh oleh psikolog sampai korban benar-benar sembuh. Biaya penanganan seluruhnya menggunakan pelayanan Badan Penyelenggara Jaminan Sosial (BPJS).

2. Strategi Sakera Jempol (Sadari Kekerasan Perempuan dan Anak dengan Jemput Bola)

Dalam program Sakera Jempol (Sadari Kekerasan Perempuan dan Anak dengan Jemput Bola), digunakan beberapa strategi penanganan para korban kekerasan, yaitu :29

1) Kampanye anti kekerasan

Kampanye kekerasan ini meliputi kader, fanspage, Molin dan Torlin. Kampanye ini dilakukan di berbagai desa yang notabene desa tertinggal yang banyak terjadi kekerasan dalam rumah tangga dengan menggunakan Molin (Mobil Perlindungan Perempuan dan Anak) dan Torlin (Motor

29 Kokok Adi Prayogo, Wawancara, inovator dan subbag bagian perencanaan program, Pasuruan, 4 januari 2019. 
Perlindungan Perempuan dan Anak). Kampanye ini dilakukan untuk mempromosikan program tersebut agar masyarakat di berbagai tempat bisa mengetahui dan bisa melapor tanpa harus jauh-jauh ke kantor dinas KBPP. Tidak hanya kampanye ke berbagai desa, kampanya juga dilakukan melalui fanspage di social media seperti facebook.

2) Deteksi dini dan pencegahan

Upaya untuk mengurangi angka kekerasan dalam rumah tangga selanjutnya adalah menyebarluaskan Hotline Jempol, yaitu kartu yang berisi nomor telepon bagi para korban yang ingin melaporkan adanya tanda-tanda kekerasan. Kartu ini telah disebarluaskan di berbagai desa terpencil yang angka kekerasannya lebih tinggi. Di berbagai desa juga dibentuk kader-kader yang bertugas mengawasi dan melaporkan jika terdapat tanda-tanda kekerasan terhadap perempuan dan anak.

3) Penanganan 3 cepat

Penanganan 3 cepat adalah penanganan korban dengan 3 strategi, yaitu cepat terdeteksi, cepat terlaporkan, dan cepat tertangani. Jika terdapat tanda-tanda kekerasan, maka perangkat desa ataupun kader mengisi kartu pengaduan. Korban kekerasan akan mendapatkan upaya penanganan secara cepat 1x24 jam. Kantor dinas KBPP juga bekerja sama dengan berbagai instansi agar mudah menangani para korban, yaitu KBPP, Dinas sosial, Lembaga Perlindunga Anak, Lembaga Bantuan Hukum, universitas dan kepolisian. Dinas sebagai leading sektor program ini, berperan sebagai koordinator pelaksanaan strategi inovasi.

Pemerintah Desa memfasilitasi keberadaan informan kunci. Rumah Sakit dan Puskesmas menyediakan perawatan untuk para korban, dinas Sosial berperan memfasilitasi proses rehabilitasi para korban, Universitas Yudharta menyediakan psikolog untuk bantuan dan rehabilitasi korban. Lembaga Perlindungan Anak memberikan pendampingan korban dan mengawal proses hukum bagi pelaku agar mendapatkan hukum yang setimpal, sementara Yayasan Bantuan Hukum Bhakti Perintis memberikan bantuan hukum dan memfasilitasi penyelesaian kasus. 
Polisi memiliki peran sebagai berikut :

1) mengakomodasi pengaduan masyarakat

2) memfasilitasi proses penerbitan surat visum et repartum untuk proses pemeriksaan yang dilakukan di rumah sakit, dan

3) mengoordinasikan proses/laporan kasus. Organisasi Pemberdayaan Kesejahteraan Keluarga di desa/kecamatan/kabupaten, Organisasi Kelompok Wanita, Organisasi Keagamaan dan Wanita, tokoh masyarakat dan kelompok relawan, memiliki peran mendukung kampanye anti kekerasan melalui facebook-fanspage atau secara langsung melakukan sosialisasi proses laporan dan penanganan kekerasan serta memberikan pendampingan bagi para korban ketika mereka kembali ke masyarakat.

4) Pendampingan berkelanjutan. Pendampingan berkelanjutan adalah pendampingan pada korban setelah penanganan kasus, yaitu saat proses rehabilitasi, saat ke psikolog, saat pengecekan di rumah sakit, dan adaptasi di masyarakat. Petugas yang mendampingi korban adalah penyuluh dari tempat desa korban tersebut.

Efektivitas Undang-Undang No 23 Tahun 2004 Terhadap Pelaksanaan Program Sakera Jempol (Sadari Kekerasan Perempuan dan Anak dengan Jemput Bola)

Didalam pelaksanaan Program Sakera Jempol ini, ada beberapa poin yang perlu dianalisis menggunakan Undang-Undang No 23 Tahun 2004 tentang Penghapusan Kekerasan dalam Rumah Tangga. Antara lain :

a. Tahap Pelaporan

b. Tahap penanganan dan perlindungan

c. Dan tahap rehabilitasi

Korban Kekerasan dalam rumah tangga butuh penanganan khusus dan perlindungan hukum karena pada dasarnya kebanyakan dari korban KDRT mengalami penderitaan secara fisik, seksual, dan psikis. Penanganan dan perlindungan hukum bagi para korban KDRT dapat diberikan melalui pendampingan korban KDRT yang nantinya akan bertugas untuk melindungi para korban dan menyelesaikan masalah para korban KDRT. Penanganan dan perlindungan hukum dapat diberikan melalui kebijakan hukum 
dengan memberikan bantuan hukum dan perlindungan bagi korban KDRT.

Pemerintah mempunyai kewajiban untuk memberikan perlindungan dan pelayanan hukum terhadap korban KDRT, yang dijelaskan dalam UU PKDRT Pasal 11, bahwa pemerintah bertanggung jawab dalam upaya pencegahan kekerasan dalam rumah tangga. Dalam pasal 13 dijelaskan :

Untuk penyelenggaraan pelayanan terhadap korban, pemerintah dan pemerintah daerah sesuai dengan fungsi dan tugas masing-masing dapat melakukan upaya :

a. penyediaan ruang pelayanan khusus di kantor kepolisian

b. penyediaan aparat, tenaga kesehatan, pekerja sosial, dan pembimbing rohani,

c. pembuatan dan pengembangan sistem dan mekanisme kerja sama program pelayanan yang melibatkan pihak yang mudah diakses oleh korban dan

d. memberikan perlindungan bagi pendamping, saksi, keluarga, dan teman korban.

Pemerintah bekerjasama dengan berbagai instansi dengan tujuan untuk membantu para korban KDRT. Salah satunya dengan bekerjasama dengan instansi yang mengembangkan sistem program pelayanan yang melibatkan pihak yang mudah diakses oleh korban sesuai dengan UU PKDRT Pasal 13.

Upaya penanganan Kasus kekerasan dalam rumah tangga menurut Undang-Undang No 23 Tahun 2004 tentang Penghapusan Kekerasan dalam Rumah Tangga berupa :

1. Pelaporan dan perlindungan

Upaya penanganan dan pendampingan khusus bagi korban KDRT dilakukan jika terdapat laporan tentang adanya kekerasan terhadap korban yang disampaikan oleh pelapor. Maka layanan khusus dilakukan sesuai dengan peraturan yang berlaku, mulai dari konsultasi, pendampingan, dan rehabilitasi. Adapun dengan penyediaan aparat, dalam hal korban yang telah melapor akan mendapatkan perlindungan sementara oleh kepolisian. Kepolisian wajib meminta surat penetapan perintah dari pengadilan sesuai dengan pasal 15, 16, 17, dan pasal $26 \mathrm{UU}$ PKDRT. 
Dijelaskan dalam pasal tersebut, bahwa jika menerima laporan kekerasan dalam rumah tangga, maka kepolisian wajib segera memproses kasus tersebut dan memberikan perlindungan untuk sementara pada korban. Dalam hal pelaporan, Pada pasal 16 ayat (1) UU No 23 Tahun 2004 dijelaskan, bahwa dalam waktu $1 \times 24$ jam terhitung sejak mengetahui atau menerima laporan kekerasan dalam rumah tangga, kepolisisan wajib segera memberikan perlindungan sementara pada korban. Korban juga bisa melaporkan secara langsung kekerasan yang dialaminya kepada pihak berwajib ataupun korban bisa memberikan kuasanya kepada keluarga atau orang lain untuk melaporkan kejadian tersebut. Dalam UU PKDRT memang tidak dijelaskan secara rinci mengenai tahap pelaporan. Namun dengan adanya ketentuan perundangan tersebut telah cukup dipahami, bahwa pihak kepolisian harus segera memproses dan melakukan penyidikan setelah menerima laporan tentang kekerasan. Selain itu, tidak hanya pihak aparat saja yang menerima laporan, setiap orang yang melihat ataupun mendengar terjadinya kekerasan, wajib segera memberikan pertolongan darurat dengan cara menghentikan terjadinya kekerasan, memberikan perlindungan dan melaporkan pada pihak berwajib.

\section{Penanganan}

Upaya penanganan pada korban KDRT dilakukan dengan memberikan pelayanan kesehatan dan konseling pada korban KDRT. Dalam hal meberikan pelayanan kesehatan kepada korban KDRT, tenaga kesehatan harus memeriksa kesehatan korban dan membuat laporan tertulis hasil pemeriksaan terhadap korban atau surat keterangan yang memiliki kekuatan hukum sebagai alat bukti. Pelayanan kesehatan tersebut, harus dilakukan di sarana kesehatan milik pemerintah, pemerintah daerah, atau masyarakat sesuai dengan UU No 23 Tahun 2004 Pasal 21.

Pekerja sosial juga harus memberikan pelayanan terhadap korban KDRT. Pekerja sosial biasanya melakukan konseling terhadap korban KDRT dan memberikan perlindungan yang dilakukan di rumah aman milik pemerintah, pemerintah daerah, atau masyarakat sesuai dengan UU No 23 Tahun 2004 Pasal 22. 
Dijelaskan bahwasannya penanganan pada korban KDRT menurut Undang-Undang No 23 Tahun 2004 adalah memberikan pelayanan kesehatan dan konseling terhadap korban. Kedua upaya ini dilakukan secara bertahap; jikalau korban mengalami kekerasan fisik, maka akan dilakukan upaya pelayanan kesehatan. Jika tidak ditemukan adanya kekerasan fisik, tetapi hanya kekerasan psikis ataupun kekerasan lainnya, maka akan dilakukan konseling oleh pekerja sosial di rumah aman milik pemerintah ataupun pemerintah daerah.

\section{Rehabilitasi}

Ketentuan rehabilitasi dijelaskan dalam Undang-Undang No 23 Tahun 2004 Pasal 40 ayat 2 Undang-Undang No 23 Tahun 2004. Tahap rehabilitasi pada korban KDRT, wajib dilakukan untuk memulihkan korban dengan memberikan konseling untuk menguatkan dan memberikan rasa aman bagi korban KDRT. Keempat instansi berperan penting dalam hal pendampingan pada korban KDRT. Korban akan merasa tetap aman tanpa ancaman karena telah mendapatkan layanan hukum yang telah diatur dalam Undang-Undang yang berlaku.

Upaya Pelaksanaan program Sakera Jempol (Sadari Kekerasan Perempuan dan Anak dengan Jemput Bola) Kabupaten Pasuruan dalam menangani Korban KDRT dilakukan dalam beberapa tahap:

a. Tahap pelaporan

Dalam menangani korban KDRT, korban telah dilaporkan melalui kader di daerah korban tersebut berasal. Ataupun korban bisa datang sendiri ke kantor Dinas Keluarga Berencana dan Pemberdayaan Perempuan (KBPP) kabupaten pasuruan. Jika korban didampingi oleh kader, korban akan diberikan kartu aduan Sakera Jempol untuk diisi biodata dan aduan yang dimaksud. Dan kartu aduan tersebut akan diproses dan korban akan mendapatkan penanganan secara cepat yaitu 1x24 jam. Pada tahap pelaporan ini didalam Undang-Undang No 23 Tahun 2004 pelaporan yang dicantumkan adalah pelaporan pada kepolisian

b. Tahap penanganan 
Jika korban mengalami luka fisik, maka akan dibawa ke rumah sakit pemerintah atau pemerintah daerah untuk di visum dan ditangani oleh petugas pelayanan kesehatan sesuai dengan prosedur. Petugas kesehatan lalu membuat laporan secara tertulis untuk dijadikan sebagai alat bukti. Disini korban akan didampingi dan dilayani sampai benar-benar sehat. Jika korban dalam keadaan baik dan tidak ditemukan luka fisik setelah visum, maka korban akan dibawa ke kantor dinas Keluarga Berencana dan Pemberdayaan Perempuan (KBPP) untuk melakukan konsultasi mengenai peristiwa yang terjadi antara korban KDRT dengan pelaku. Disini korban akan tetap didampingi sampai konsultasi benar-benar berakhir. Korban juga akan mendapatkan layanan bantuan hukum dan fasilitas penyelesaian kasus.

c. Tahap rehabilitasi

Setelah selesai tahap konsultasi, korban akan memasuki tahap rehabilitasi yang dilakukan kantor dinas KBPP guna mengetahui keadaan psikologis korban. Jika terjadi gangguan psikologis, maka akan didampingi untuk menemui psikolog yang telah ditunjuk oleh pemerintah, yaitu dari Universitas Yudharta yang bekerjasama dengan lembaga konsultasi psikolog.

Jadi disini, korban ditangani secara langsung dan mendapatkan perlindungan sementara. Begitu juga dengan proses pelaporan pada kantor dinas Keluarga Berencana dan Pemberdayaan Perempuan, ditangani secara langsung begitu ada laporan tentang kasus kekerasan dalam rumah tangga.

Upaya pelaksanaan Program Sakera Jempol (Sadari Kekerasan Perempuan dan Anak dengan Jemput Bola) Kabupaten Pasuruan dalam menangani kasus KDRT telah sesuai dengan UndangUndang No 23 Tahun 2004 tentang Penghapusan Kekerasan dalam Rumah Tangga. Dari tahap Pelaporan, tahap penanganan, hingga tahap Rehabilitasi telah tepat sasaran dan hak-hak korban KDRT juga terpenuhi sesuai dengan aturan yang berlaku.

Begitu juga dengan Pasal 22 ayat 3 UU PKDRT menjelaskan keharusan mengantar korban ke rumah aman atau tempat tinggal alternatif. Ketentuan ini juga diterapkan, korban yang butuh 
perlindungan, dijauhkan dari pelaku kekerasan dengan menempatkan korban di rumah aman milik pemerintah atau pemerintah daerah. Selain itu, di dalam Undang-Undang No 23 Tahun 2004 Pasal 5 terdapat beberapa jenis kekerasan yaitu kekerasan fisik, kekerasan seksual, kekerasan psikis, dan penelantaran rumah tangga, tetapi yang ditangani oleh program Sakera Jempol hanya kekerasan seksual dan kekerasan fisik, sementara jenis kekerasn lainnya belum tertangani. Untuk itu, perlu penanganan korban perlu diperluas, tidak hanya kekerasan fisik dan seksual tetapi juga kekerasan psikis dan penelantaran rumah tangga demi menciptakan rasa keadilan dan ketentraman sesuai dengan asas keadilan gender.

Pada Periode 2015-2018 terdapat sejumlah kasus kekerasan yang ditangani oleh Kantor Dinas KBPP melalui program Sakera Jempol (Sadari Kekerasan Perempuan dan Anak dengan Jemput Bola). Mulai dari Tahun 2015 terdapat 68 kasus yang terdiri dari 3 laki laki dan 65 perempuan, Tahun 2016 terdapat 86 kasus yang terdiri dari 15 korban berjenis kelamin laki-laki dan 71 korban berjenis kelamin perempuan, Tahun 2017 terdapat 69 kasus yang terdiri dari 2 korban berjenis kelamin laki-laki dan 67 korban berjenis kelamin perempuan, dan Tahun 2018 terdapat 21 kasus yang terdiri dari 21 korban berjenis kelamin perempuan. Jika diamati, dari data Distribusi Rasio, terlihat terutama pada tahun 2017 mengalami penurunan berjumlah 69 Kasus, yang artinya Program Sakera Jempol ini mulai efektif pada Tahun 2017.

Adapun jenis kekerasan yang terjadi menurut Kantor Dinas KBPP Kabupaten Pasuruan. Pada tahun 2015 terdapat 30 kasus pelecehan seksual dan 35 kekerasan fisik, Tahun 2016 terdapat 11 kasus pelecehan seksual dan 54 kasus kekerasan fisik, Tahun 2017 terdapat 16 kasus kekerasan seksual dan 51 kasus kekerasan fisik, dan pada Tahun 2018 tercatat 5 kasus pelecehan seksual dan 16 kasus kekerasan fisik. Dapat disimpulkan, bahwa kasus kekerasan seksual dan fisik tertangani dengan baik karena adanya penurunan pada Tahun 2018 yang berjumlah menjadi 21 kasus.

Berdasarkan dari grafik kecepatan penanganan kasus kekerasan perempuan dan Anak pada periode 2015-2018, kecepatan dalam menangani kasus mengalami peningkatan di setiap tahunnya, yaitu 
pada Tahun 2015, kecepatan penanganan kasus kekerasan terhadap perempuan dan Anak 5 hari. Tahun 2016, kecepatan penanganan kasus 3 hari, dan di Tahun 2017 sampai dengan tahun 2018, kecepatan penanganan kasus hanya 1 hari saja.

Berdasarkan grafik dari distribusi jumlah kasus kekerasan perempuan dan anak periode 2015-2018 dan grafik kecepatan penanganan kasus kekerasan perempuan dan anak periode 20152018, dapat disimpulkan bahwa program Sakera Jempol (Sadari kekerasan Perempuan dan Anak dengan Jemput Bola) dalam menangani kasus KDRT berjalan cukup efektif.

Program ini dinyatakan cukup efektif, karena mulai dari periode 2015-2018 sebanyak 244 kasus yang ada, dari tahun 2015 yang berjumlah 68 kasus hingga Tahun 2018, menurun menjadi 21 kasus KDRT. Program Sakera Jempol (Sadari kekerasan Perempuan dan Anak dengan Jemput Bola) berhasil menurunkan Angka kekerasan terhadap perempuan dan Anak dan penyelesaian kasus KDRT dari 5 hari penyelesaian menjadi 1 hari saja.

\section{Penutup}

Dalam menangani korban kekerasan dalam rumah tangga, Program Sakera Jempol (Sadari Kekerasan Perempuan dan Anak dengan Jemput Bola) Kabupaten Pasuruan mempunyai beberapa Upaya penanganan, diantarany, memberikan pelayanan terbaik secara medis, psikologis, dan hukum. Serta mendampingi korban mulai dari tahap pelaporan hingga tahap rehabilitasi.

Upaya pelaksanaan program Sakera Jempol (Sadari Kekerasan Perempuan dan Anak dengan Jemput Bola) Kabupaten Pasuruan dalam melindungi korban KDRT telah sejalan dengan UndangUndang No 23 Tahun 2004 tentang Penghapusan Kekerasan dalam Rumah Tangga dan telah terciptanya keadilan berdasarkan nilai-nilai kemanusiaan yang tercermin melalui profesionalitas kinerja Program Sakera Jempol (Sadari Kekerasan Perempuan dan Anak dengan Jemput Bola) dalam melayani korban KDRT.

\section{Daftar Pustaka}

Farha Ciciek. Ikbtiar Mengatasi Kekerasan Dalam Rumah Tangga, Jakarta: The Asia Foundation, 1999. 
Fathul Djannah Dan Rustam. Kekerasan Terhadap Istri, Yogyakarta: LkiS Yogyakarta, 2002.

Fikri Arigi. "Catatan Tahunan Komnas Perempuan" dalam

Huzaemah Tahido Yanggo. Fikih Perempuan Kontemporer, Bogor: Ghalia Indonesia, 201.

Kementrian Agama RI. Al-Qur'an dan Terjemahnya, Jakarta : Sygma Examedia, 2009.

La Jamaa dan Hj. Hadidjah. Hukum Islam \& Undang-undang Anti Kekerasan Dalam Rumah Tangga, Surabaya: PT Bina Ilmu, 2013.

Moerti Hadiati Soeroso. Kekerasan Dalam Rumah Tangga Dalam Perspektif Y uridis-Viktimologis, Jakarta: Sinar Grafika, 2011.

Mufidah. Psikologi Keluarga Islam Berwawasan Gender, Malang : UINMaliki Press, 2013.

Muhajir Arifin. "Program Sakera Jempol", dalam Https://m.detik.com/news/berita-jawatimur-programsakera-jempol.html diakses pada hari selasa tanggal 16 Oktober 2018.

Shanty Dellyana. Wanita Dan Anak Di Mata Hukum, Yogyakarta: Liberty, 1988.

Soka Handinah. Perempuan dan Kekerasan, Jakarta: Lutfansah Mediatama, 2005.

Ummu Sufyan. Senarai Konflik Rumah Tangga, Bandung: Remaja Rosdakarya, 2007.

Undang-undang No. 23 Tahun 2004 Tentang Penghapusan Kekerasan Dalam Rumah Tangga

Zohra Andi Baso Dan Dwia Aries Tina. Kekerasan Terhadap Perempuan Menghadang Langkah Perempuan, Yogyakarta: Pusat Studi Kependudukan Dan Kebijakan Universitas Gadjah Mada, 2002.

Kokok Adi Prayogo. Wawancara, inovator dan subbag bagian perencanaan program, Pasuruan, 3 januari 2019.

Iswakhiyah. Wawancara, Pasuruan, 7 Januari 2019.

Https://komnasperempuan.go.id.html diakses pada hari selasa tanggal 16 Oktober 2018.

Kokok Adi Prayogo. Wawancara, inovator dan subbag bagian perencanaan program, Pasuruan, 3 Januari 2019. 
Hadaita Na'mah: Program Sakera Jempol...... 